Pinisi Discretion Review

Volume 4, Issue 1, September, 2020 Page. 11- 260

ISSN (Print): 2580-1309 and ISSN (Online): 2580-1317

\title{
Modern Religious Slavery in Nigeria: The Christian Perspective
}

\author{
Emmanuel Williams Udoh \\ Department of Religious and Cultural Studies, \\ University of Calabar, Cross River State, Nigeria. \\ E-mail: revemmaudoh@yahoo.com
}

(Received: May-2020; Reviewed: July-2020; Accepted: July-2020;

Avalaible Online: July-2020; Published: July-2020)

(c) (1) (T) This is an open access article distributed under the Creative Commons Attribution License CC-BY-NC-4.0 @2020 by author (https://creativecommons.org/licenses/by-nc/4.0/)

\begin{abstract}
Gandhi's concept of nonviolence has a humanistic approach. He tried to change the very character of every Indian in the society where he lived. He said that man is basically a violent being, but gradually he can become non-violent if he desires. He recognizes that man is a conditional being and as such subject to the determination of the physical world. The ultimate end in man's life for Gandhi is realizing the Absolute. Pertinent to note that, Gandhi had spent quite some time in his tutelage in Southern Africa where his experiences impelled him to adopt non-violence as the only paradigm to overcome oppression and domination in his country India. British oppression and inhumanity were so severe and intensive that Gandhi was cautious about the use of violence, alternatively, he adopted non-violence to be the only imperative paradigm to dislodge the domination and inhumane treatment of the British against the Indians in South Africa. In this respect, I recommend Gandhi's non-violence principles as a fundamental paradigm towards peace in Africa. Peace in Africa is imperative for human and societal development especially as one sees Africa grappling with instabilities, insurgencies, terrorism, xenophobia, political upheavals, nepotism and gender agitations. In this article, I recognize Gandhi's postulations on nonviolence as an initiative which if adopted and its dictates are adhered to, could enhance peace in Africa.
\end{abstract}

Keywords: Christianity; administration; traditions; religious; exploitation.

\section{INTRODUCTION}

In modern society, there are elements of slavery everywhere. The present upsurge of human trafficking and child labour are common occurrences in our society. A clear indication is the current laws and emphasis on human equality, feminism, and many similar regulations to checkmate the spade of inhuman and oppressive policies, customs and traditions that are inimical to human freedom in our society.

Etymologically, slavery itself has been defined in several ways. The Bible uses the

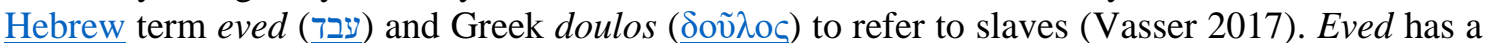


much wider meaning than the English term slave, and in many circumstances, it is more accurately translated into English as a servant or hired worker. Doulos is more specific but is also used in more general senses as well. For example, it is used of the Hebrew prophets (Rev 10:7), of the attitude of Christian leaders toward those they lead (Matt 20:27), of Christians towards God (1 Peter 2:16), and of Jesus himself (Phil 2:7).

The word slavery has been described differently by different people. It can be said here that "Slavery" is one concept that has defied a single, universally accepted definition. The reasons for this difficulty are that its origin has not been known; it was practiced by both religious and non-religious persons in the early centuries; it is also a phenomenon that has grown with humanity; scholars, in turn, looked at it from their various fields. Moreover, it has evolved from being recognized as a legal business backed by government policies at various times in history to become an acceptable way of life. However, a few of the definitions will be mentioned here. According to Ali (2010: 8), slavery is a form of control or dominion exercised by one person over another. Ottoman historian Ehud Todedano (web) described the term slavery as "a form of patronage relationship formed and often maintained by coercion, but requiring a measure of mutuality and exchange that posits a complex web of reciprocity." The term slavery must be understood for what it is. The contemporary understanding or meaning which this work adopts is "Man's inhumanity to man" or "inhumanity of man to man." (Anagaba 2008)

The practice of slavery has no identifiable origin. Its origin is difficult to ascertain. According to Charles Torrence (1901), the practice of slavery dates to prehistoric times, although its institutionalization probably first occurred in early historical times, when agricultural advances made possible more highly organised societies. Many have associated slavery with the traffic in Negro slaves which was an important feature in the trade between Europe and West Africa. In attempting to trace the origin of slavery, K. B. C. Onwubiko (1980: 75) says,

Because of the Atlantic slave trade which began in the fifteenth century, it has become fashionable, especially among people of non-African descent, to associate the concept of slavery with the people of the African continent alone. But such an idea is a gross misrepresentation of the truth. Slavery is a social institution that is as old as the human race itself. We read in the pages of the Bible of the Jews being enslaved by the Egyptians about four thousand years ago. The great pyramids of Egypt were built by slave labour. The ancient empires of Greece and Rome had more slaves than freemen at the height of their glory and power. A great proportion of Europe's peasant class in the eighteenth century were descendants of serfs or people of slave origin.

According to Onwubiko (1980), it has also been historically proven that in Africa slavery was a recognised institution. They were employed by kings, chiefs and wealthy people as domestic servants. Apart from domestic slaves, there was also plantation slavery. This social institution was practised all over the world in various dimensions.

Furthermore, when people today think of slavery, they envisioned the form in which it existed in the United States before the American Civil War (1861-1865): with one racially identifiable group owning and exploiting another. However, in other parts of the world, slavery took many different forms. In Africa, many societies recognized slaves merely as property, but others saw them as dependents that eventually might be integrated into the families of slave owners (Lovejoy 2010). Still, other societies allowed slaves to attain positions of military or administrative power. It is also a common scene in religious communities. The nature of enslavement in our contemporary society differs from what was known to be slavery during the slave trade era. The current economic meltdown resulting in a high level of poverty has heightened enslavement. Corruption has also crept into the church, resulting in selfishness, 
division, tribalism, nepotism, clique formation and leadership tussle. It must be noted that slavery was and is still abhorred by many, in whatever form it presents itself, except those who benefit from the enslavement of other people. Slavery is one social institution that has no regard for human dignity. Slaves were treated as commodities and called "human cargo" (Onwubiko 1980 261). They were bought and sold at will, forced to work and walk when tired or foot-sore, and if any resisted, he or she was given terrible beating. Onwubiko (1980) describes slaves' journey to their destinations in Europe, America and other parts of the world as "the most horrible of human suffering." The conditions in which slaves live and work can be described as nothing but terrible, dreadful and disgusting. Aside from the physical sufferings of the slaves in their various places of forced labour or service, they also suffer psychologically or mentally as a result of their hopelessness, realisation of being separated from their relations whom they would probably not see again and can do nothing to free themselves. Such scenarios are not but present in our society and in our generation. When we see, hear and read of human trafficking, child labour, marginalisation, migrant problems, underemployment, work without pay, job insecurity and corruption in our nation, it behooves on this researcher to expose this terrible social evil to safe humanity from further suffering.

This work is necessitated to expose slavery as seen in Christianity today; to show that slavery is still in existence despite its pronounced abolition worldwide; to expose the nature of modern slavery, highlighting its causes and effect and offer some suggestions on the possibility of reducing or eradicate the menace in the Church.

\section{Theoretical Framework}

This work adopts a social conflict paradigm, a framework that sees society as an area of inequality that generates conflict and change. Conflict theories emphasize the dominance of some social groups by others. A look at social change reveals changes based on manipulation and control by dominant groups and views social change as occurring rapidly and in a disorderly fashion as subordinate groups overthrow dominant groups ( Ritzer 1996 234). Conflict theory grew out of the industrial revolution, with Karl Marx and Friedrich Engels as key proponents. This theory emerged as a result of industrialization. Marx and Engels interpreted what they say as a way to eliminate capitalism, social injustice and poverty that were prevalent at that time. They did not mind the breakdown of social order that mass violence was going to result (Marx \& Engels 1962: 31).

In the views of Marx and Engels (1962), every society (or group) is divided into two classes based on the ownership of the means of production. The first of the group is the owners of the means of production (bourgeoisie), the ruling class; and the second is the people who work (the proletariat) or working class. The difference creates an automatic conflict of interests between the two groups. With this unequal position held by members of the society, conflict is bound to occur. According to it proponents "this theory emphasizes that different groups in society have different interests stemming from their different social positions." However, "these different interests, in turn, lead to different views on important social issues."

This theory will be used to analyze the different situations taking place in our churches. The current situation whereby Church leaders, General Overseers, Bishops and so on see themselves as bourgeoisies and regard the subordinates as the proletariat or workers and treat them as people of unequal status, denying them their rights and privileges, has resulted to conflicts. Later, the subordinates are subjected to situations and status equals that of slaves.Researcher using the social conflict theory looks at ongoing conflict between dominant and disadvantaged categories of people in our Christian churches today. As usual, people on 
top strive to protect their privileges, while the disadvantaged try to secure what they have and try to gain more for themselves.

Also suitable in this work is the theory called utilitarianism postulated by Cesare Beccaria (1738-1794) and Jeremy Bentham (1748-1832). This theory views human behaviour generally as people acting to maximize their pleasure and to reduce their pain. The postulators thought that people act rationally and decide before they act whether their behaviour will cause them more pleasure or pain (Kilbride 2013). In sociology, the name for this theory is "exchange theory" or "rational choice theory." When people interact, they seek to maximize the benefits they gain from the interaction and to reduce the disadvantages. If they decide that the interaction benefits outweigh its disadvantages, they will initiate the interaction or continue it if it is already underway or vis-a-vis. Social order is possible because people realize it will be in their best interests to cooperate and to make compromises when necessary. This analysis is true of the Christian Church hierarchy. The leaders relate with the members in this manner. They ensure that their position and interest is always protected. Because of the benefits that accrue to them being in a vantage position, they fight to protect it. Laws and policies are changed overnight to keep them in position. The members will also make some compromises to enable them to continue in their relationship with God, which to them is their greatest benefit. This is why church members are in perpetual slavery.

\section{Types of Slavery}

Several types of slaves have been known in history. There have been Slaves by legislation. These were those who were made or became slaves by the law of the land. There were also slaves by marriage contracts. This includes females sold into concubinage by impoverished parents (Douglass 1994: 343). Aquinas explained that the view that children of a slave mother become slaves even though they have not committed a personal sin, this view was cited and confirmed by later Popes (Pich 2019).

The next category of slaves is indentured servants. These were apprentices or servants who, by contract committed to serving their masters or employers for a specific period of time. There were also slaves by voluntary enslavement. This was common in poor communities where people voluntarily sell themselves into slavery for a fixed period either to pay off debts or to get food and shelter (Leviticus 25:35). Also popular during the known slave trade era was the practice of slavery by capture. These were slaves obtained through warfare (Deut. 20:10-16) but not through kidnapping (Deut. 24:7, Ex. 20:10-16). Salves (children) were children sold into debt bondage (Lev. 25:44), this was sometimes ordered by a court of law (Is. 22:2-3; 2 Kings: 4:1-7).

Christian views on slavery are varied both regionally and historically. Slavery in various forms has been a part of the social environment for much of the history of Christianity, spanning well over eighteen centuries (Kirchschlaeger 2016). In the early years of Christianity, slavery was a normal feature of the economy and society in the Roman Empire, and this persisted in different forms and with regional differences well into the Middle Ages. Saint Augustine described slavery as being against God's intention and resulting from sin (Glancy 2010). In the eighteenth century, the abolition movement took shape among Christian people across the globe. Slavery was frequently analogized to marriage: both were forms of control or dominion exercised by one person over another. To discuss marriage in the pre-modern period without reference to slavery would fundamentally distort the jurists' ways of thinking; the one was bound up with the other, even more so in legal thinking than in actual practice (Ali 2010: 8; see Alumuna et al., 2017). The record of the Anglican Church was no better than that of the Roman Church. It was the universal opinion of churchmen that God had ordained slavery, and 
clergymen had no qualms about owning slaves themselves. Anglican slave traders were often extremely devout and widely respected by their fellow Christians. It never occurred to them, or to their priests or ministers that slave trading might be immoral.

Today we have several other forms of slavery being perpetuated by Christians even within their Christian fold. These views were obtained through oral interviews with selected Christians. The selection cuts across denominations, the clergy as well as the laity. Their views were very revealing. One area of slavery still being experienced in Christianity is doctrinal. What makes a denomination different from another are basically three factors: doctrinal, practice and procedure. Most Christian denominations hold tight to their members through indoctrination. From childhood, they are taught certain things that make them different from other Christian groups. One respondent, Okon Samson, a layperson in the Catholic church confirmed that they are taught from childhood what to believe and what not to believe; not to accept any other view on such matters as touching those areas. Citing prayer as an example, he continued by saying that they are told not to copy any other form of prayer except that taught them in their Church. Glory Okon of Deeper Life Church also affirmed the reason given by Samson as the reason they are not comfortable in any other church and in fact see other churches as unspiritual.

Another way that today Christianity has enslaved her membership is through behavioural rules. This has to do with their mode of dressing, celibacy, and strict marital rules that is where they are barred from marrying outside their fold. Any deviation is viewed seriously and attracts discipline on parents that give consent to such marriage by their children. A young undergraduate female student, Scholastica Okorie, of Catholic denomination during an oral interview objected to marrying outside her denomination, because she has to protect the interest of her parents in the church. There is yet another type of enslavement in Christianity today which the researcher calls "subjection." This is a case were church workers are subjected to poor working conditions. They are poorly paid, some without fix emolument. They are subjected to the dictates of the superior officers. A pastor in the Assemblies of God Church lamented on poor treatment by his superior. According to this pastor whose name he gave as Ewa Owora said, in AG Ministers or Pastors by the policy of the church are not regarded as employees. No salary is paid them, they are only entitled to an unfixed allowance. Besides, they are expected to make returns to the District every month, and sometimes after the exercise, the pastor may be left with nothing. Another Pastor of the same church, S. E. Okeke said that the situation is pathetic, but there are attempts are being made by the young pastors to change the system. Because at present it is the man at the top that it benefits most. That is why we experience leadership tussle in AG. Gender inequality is another way members of the Church are being enslaved. A woman leader, Margaret Ekpenam in the Apostolic Church asked, why are women not ordained Pastors or Elders in your Church. She retorted "I don't know", but I think, the woman has to work under the man. In his swift reaction, her husband a pastor said women have other roles to play but the office of the Pastor or Elder is reserve strictly for the male. Women have a lot to do in the church, they prophesy, speak in tongues, teach the children Sunday School, sing in the choir. Under this condition, women are subjected to work under men, their spiritual gift, status and ability notwithstanding, she is limited to what she could do.

\section{Causes of Slavery}

William John Chrysostom (web) described slavery as "the fruit of covetousness, of degradation, of savagery; the fruit of sin and of human rebellion against...our true Father (1) in his Homilies on Ephesians. Aristotelian teaching that some people are slaves "by nature", like inanimate instruments, because of their sins; for since the slave cannot work for his own benefit slavery is necessarily a punishment (Moutsopoulos 2015; Duke \& Osim 2020). The humiliating 
and undignified state of slavery motivated Wilberforce in England to determine to stop it and reform morals in his society. He wrote in his diary when he was 28 that, "God Almighty has set before me two great objects, the suppression of the Slave Trade and Reformation of Morals" (Foley 2014). Unbelief attracted discipline which was sentence to slavery by the authorities. A lot of Popes sentenced millions to slavery, although the sentences could not always be carried out. The Third Lateran Council 1179 imposed slavery on those helping the Saracens. The same council also imposed slavery on anyone who opposed the papacy. Pope Nicholas V issued the papal bull Dum diversas on 18 June, 1452. It authorized King Alfonso V of Portugal to reduce any Saracens (Muslims) and pagans and any other unbelievers to perpetual slavery.

The record of the Anglican Church was no better than that of the Roman Church. It was the universal opinion of churchmen that God had ordained slavery, and clergymen had no qualms about owning slaves themselves. Anglican slave traders were often extremely devout and widely respected by their fellow Christians. It never occurred to them, or to their priests or ministers that slave trading might be immoral.

\section{Effects of the Slave Trade}

Social - In the past there was a great loss of population caused through the slave trade (Fage 1962). Today there is disrespect for constituted authority workers who have no respect for their employers due to the harsh and oppressive attitude of the latter. The activities of employers have lowered the quality of people; retarded growth of the workers; break up of traditional social order. Following the soar relationship between church leaders and their subordinates, and the resultant anarchy and confusion, that undermined the missions and detribalised or displaced, the subordinates were let loose upon their leaders. The proliferation of churches in Nigeria might perhaps have been the effect of the oppressive, nonchalant, and "slave master" attitude of our today church leaders.

Political - The need to better their working conditions, workers have resulted into organising themselves into labour union to protect and defend their interest in the organisation (Ogar et al., 2018, Ushie 2018; Duke \& Okafor 2020). The organisation becomes a battlefield when it comes to an elective office. The majority will tilt to supporting a candidate that will improve their condition by voting such a candidate. The oppressed workers will explore all avenues to improve their welfare while in service. Pastor Aniefiok Ibanga, speaking during an oral interview saw this as the reason why filling of elective positions are always tensed. According to him, sometimes, even church leaders employ all forms of intimidation, blackmail and diabolical means in an attempt to secure the position. Elder Sunday Ukpong added a voice affirming that these are some of the reasons why there is the proliferation of churches. People don't want to work under a "slave" like circumstance. So they prefer establishing theirs with different name and locations.

Economic - Slavery is the determinant of where the wealth of that organization or society flows to. In an establishment where people work under corrupt officials who treat the workers as slaves, the workers will suffer while the officers will amass wealth. This is a reminder of the reason Karl Marx (1962) described religion as the "opium of the people" (Udoh 2017). The works will be submissive, obedient and hardworking while the few leaders enriched themselves from the sweat of the "slaves" who labour day and night. The workers are chained with policies, harsh contract agreements, the oath of allegiance, and hard-work. This they will keep to it since they have no other option. Slavery retards the economic development and progress of the people. When the government fails to create jobs by diversifying the economy, the labour market will become overpopulated with people looking for just anything to do. With this kind of situation, people succumb to any situation at their disposal. A Pastor of a rural 
church, Michael Sunday Etuk attests to the fact that he has become like a human property in the hands of the church leaders. According to him, he has to remain and get the little he is paid monthly.

Cultural - In the days of slave trade cultural progress was retarded; a high standard of art and culture that flourished in several states of West Africa in the $15^{\text {th }}$ and $16^{\text {th }}$ centuries diminished or degenerated in the $19^{\text {th }}$ century owing to the destructive influence of slave trade (Yta 2015). It therefore will mean that people are no longer able to live and develop their culture naturally, and the community will be debased, corrupt and unorganised (Abel \& Uket 2016; Udoudom et al 2018; Enor et al 2019). Because of a lack of direction, the few will rule the majority by intimidation and torture.

Inhumanity - The slavery in whatever form is always brutal and immoral and no one could participate in it without being brutalised and demoralised. Mpofu (2017) observed that it introduced into West Africa the worst aspects of European character. And there was a general contagion of treachery, dishonesty, vice and debauchery perpetrated by the naturally moralminded peoples of West Africa (Mpofu 2017). What more can be said, when people are denied the basic needs of life, owed their benefits, intimidated, and working under inhuman conditions, it is obvious to regard such workers as slaves, having no voice and no right to exercise.

\section{slavery and christianity then and now}

It would be appropriate to bring down the testimony of a Christian slave who spoke of his time in the hands of Christian slave owners. This testimony illustrates or lay bay the facts that would not otherwise be told by the perpetrators of the crime. Although Frederick Douglass (1994) was a Christian believer himself, his testimony against mainstream Christians is excoriating. Here it is in a nutshell.

Were I to be again reduced to chains of slavery, next to that enslavement, I should regard being the slave of a religious master the greatest calamity that could befall me... [I] hate the corrupt, slaveholding, women-stripping, cradle plundering, partial and hypocritical Christianity of this land (Douglass 1994: 343).

And here it is, in more detail:

... I am filled with unutterable loathing when I contemplate the religious pomp and show, together with the horrible inconsistencies, which everywhere surround me. We have men-stealers for ministers, women whippers for missionaries, and cradle-plunderers for church members. The man who wields the blood-clotted cow skin (whip) during the week fills the pulpit on Sunday and claims to be a minister of the meek and lowly Jesus. The man who robs me of my earnings at the end of each week meets me as a class-leader on Sunday morning, to show me the way of life, and the path of salvation. He who sells my sister, for purposes of prostitution, stands forth as the pious advocate of purity. He who proclaims it a religious duty to read the Bible denies me the right of learning to read the name of the God who made me. He who is the religious advocate of marriage robs whole millions (of slaves) of its sacred influence and leaves them to the ravages of wholesale (moral) pollution. The warm defender of the sacredness of the family relation is the same that scatters whole families, - sundering husbands and wives, parents and children, sisters and brothers, leaving the hut vacant, and the hearth desolate. We see the thief preaching against theft and the adulterer against adultery. We have men sold to build churches, women sold to support the gospel, and babes sold to purchase Bibles for the poor heathen! all for the glory of God and the good of souls! The slave auctioneer's bell and the church-going bell chime in with each other, and the bitter cries of the heartbroken slave are drowned in the religious shouts of his pious master. Revivals of religion 
and revivals in the slave-trade go hand in hand together. The slave prison and the church stand near each other. The clanking of fetters and the rattling of chains in the prison, and the pious psalm and solemn prayer in the church, maybe heard at the same time. The dealers in the bodies and souls of men erect their stand in the presence of the pulpit, and they mutually help each other. The dealer gives his blood-stained gold to support the pulpit, and the pulpit, in return, covers his infernal business with the garb of Christianity. Here we have religion and robbery the allies of each other-devils dressed in angels' robes, and hell presenting the semblance of paradise.

I assert most unhesitatingly, that the religion of the South is a mere covering for the most horrid crimes - a justifier of the most appalling barbarity, a sanctifier of the most hateful frauds, and a dark shelter under which the darkest, foulest, grossest, and most infernal deeds of slaveholders find the strongest protection. Were I to be again reduced to the chains of slavery, next to that enslavement, I should regard being the slave of a religious master the greatest calamity that could befall me... I... hate the corrupt, slaveholding, women-whipping, cradle-plundering, partial and hypocritical Christianity of this land (Douglass 1994: 343).

And he said this - indicating that slave owners who become Christians became worse masters:

... and when you tell me that there are some Christian slave-holders in the States, I tell you, as well might you talk of sober-drunkards. Just as if the lash in the hands of a Christian is not as injurious to my back as it would be in the hands of a wicked man. As far as my experience goes, I would rather suffer under the hands of the latter, and, I tell you, as I have mentioned in my narrative, that next to being a slave, there is no greater calamity than being the slave of a Christian slaveholder. I say this from my own experience.... Some persons have taken offense at my saying that Slaveholders become worse after their conversion (Douglass 1994: 343).

This ravenous act of owning slaves by Christians continued for centuries despite criticism from rationalists and freethinkers. The overview of the above testimony reveals that the Church and her leaders were directly involved in the slavery business. Not seeking the salvation of men but the comfort of their zone or body; with intimidating and coursing, messages and deceitful prophesies luring the spiritually weak to further impoverish them.

\section{CONCLUSION}

Slavery is a long-standing model of ensuring that people are not free to achieve their potentials. It is a crime against humanity. When Church leaders engage in dubious politicking, formulation of policies in their favour, undermine the dignity of others under them, it is an act of enslavement. This act has been noted by the interviewees above. The resultant effect is that adherents are psychologically, spiritually and socially enslaved. When members of a church are not allowed to exercise their spiritual gift(s) freely just because they are female, subordinate, lay or what have you. The person is being enslaved. When religious tradition(s) does not allow for free participation and equal treatment, but favouritism, nepotism and such negative vices, it is enslavement.

To continue to perpetuate these inhuman practices, some church organizations embark on indoctrination and dogmatism. In an interview with to a member of a particular church organization, Modey Adeniji, his pastor taught the members that reciting the "Lord's Prayer" 
was wrong, that Jesus did not teach that as a prayer to be said repeated by Christians. For that reason, the see those other denominations who recite the Lord's Prayer as sinners and so disassociate themselves from such churches. Another interviewee Chukwudi Sunday Ahamefula, lamented that the policy of posting workers in their Church gives no room for him to serve in the city church. It is only the favoured of the Bishop that enjoys such privileges. He decried his being neglected by his Bishop. Parents have threatened to denounce their daughter if they marry someone outside their particular denomination. The parents feared being reduced to ordinary floor members if their daughter marries outside their denomination (Oral interview with Emmanuela Chizom). In the above stories, one can sense signs of frustration, dissatisfaction, and rejection. Slavery in Christianity cuts across members and the clergy. These attitudes have plagued the church with corruption, immorality, power tussle and split for so long.

There is, therefore, the need for religious organizations, particularly the church to review their undemocratic procedures of appointing leaders; annul long-standing traditions that have become obsolete in our contemporary society; allow members to enjoy the freedom to share in the worship of other Christian denomination of their choice and not be bound by tradition and other inhuman rules. Slavery should be abolished in every facet of Christianity. However, if the world needs to emulate the Church, then the latter must prove itself to be worthy of what it preaches. It must show that it is capable of changing the world positively.

\section{REFERENCES}

Abel, U. I., \& Uket, A. J. (2016). Epistemology and education: locating a cynosure and creating a nexus for authentic national development. Sophia: An African Journal of Philosophy, 16(2), 88-96.

Ali, K. (2010). Marriage and Slavery in Early Islam. Massachusetts: Harvard UP.

Alumuna, S., Ofoegbu, R. C., \& Edet, A. S. (2017). Militancy and Kidnapping in the Niger Delta Region of Nigeria; A Recap. Elixir Social Studies 112 (2017) 49425-49434.

Anagaba, S. M. (2008). Man's inhumanity to man. In Colonial Systems of Control: Criminal Justice in Nigeria (pp. 153-156). https://doi.org/10.1093/nq/s6-xii.303.314h

Anene, J. C. (1999). Essays in African History $19^{\text {th }} \& 20^{\text {th }}$ Centuries. Ibadan: Onibonoje Press.

Chrysostom, John. "Homily 22 on Ephesians". http://www.newadvent.org/fathers/230122htm. Retrieved 21 July 2018.

Douglass. F. (1994), Autobiographies: Narrative of a Life, My Bondage and My Freedom, Life and Times, Henry L. Gates, Jr., ed. New York, Library of America, cited by Sagan, The Demon-Haunted World. 343.

Duke, E. O., \& Okafor, J. O. (2020). Poverty Alleviation Policies of Selected Churches in Anambra State, Nigeria. GNOSI: An Interdisciplinary Journal of Human Theory and Praxis, 3(1), 40-52.

Enor, F. N., Edet, A. S., \& Etim, A. E. (2019). Archaeology, History and the Monoliths Heritage: Nta Akwansisi in Perspective. Academic Journal of Interdisciplinary Studies, 8(3), 248-248.

Fage, J. D (1962). Introduction to the History of West Africa. Cambridge: Cambridge UP.

Foley, P. (2014). Modern slavery and the role of business | Ethical Corporation. Ethical Corporation. http://www.ethicalcorp.com/supply-chains/modern-slavery-and-rolebusiness

Glancy, J. A. (2010). Embodying Slavery from Paul to Augustine. In Corporal Knowledge (pp. 48-80). https://doi.org/10.1093/acprof:oso/9780195328158.003.0003 
Kilbride, D. (1993). Slavery and Utilitarianism: Thomas Cooper and the Mind of the Old South. The Journal of Southern History, 59(3), 469. https://doi.org/10.2307/2210004

Kirchschlaeger, P. G. (2016). Slavery and early Christianity- a reflection from a human rights perspective. Acta Theologica, 2016, 66-93. https://doi.org/10.4314/actat.v23i1S.4

Lovejoy, P. E. (2010). Slavery in Africa. In The Routledge History of Slavery (pp. 35-51). https://doi.org/10.4324/9780203840573-8

Marx, K. and Engels, F. (1962) "The Common Manifesto. "Marx and Angels: Selected Works. Moscow: Foreign Language Publishing House. 21-65.

Moutsopoulos, E. (2015). Aristote sur les crises morales et économiques. Revue Roumaine de Philosophie, 59(2), 239-251.

Mpofu, W. (2017). Decoloniality as a combative ontology in African development. In The Palgrave Handbook of African Politics, Governance and Development (pp. 83-102). https://doi.org/10.1057/978-1-349-95232-8 5

Ogar, J. N., Idagu, U. A., \& Bassey, S. A. (2018). Ethics in a technological society. Journal of Sustainable Society, 7(1), 1-4.

Onwubiko, K. C. (1980). History of West Africa: A.D 1000-1800. Onitsha: Africana.

Pich, R. H. (2019). John duns scotus on slavery. Trans/Form/Acao, 42(Special Issue), 291-332. https://doi.org/10.1590/0101-3173.2019.v42esp.16.p291

Ritzer, G. (1996). Sociological Theory. Maryland: McGraw-Hill.

Torrence, C. (1901). "Slaves and Slavery." Jewish Encyclopadea. 892-905

Udoh, E. W. (2017). The Issues of Contention between Religion And Culture In Africa: A Comparative Analysis. Leajon: An Academic Journal of Interdisciplinary Studies. 8 (2), 114-125

Udoudom, M. D., Idagu, U. A., \& Nwoye, L. (2018). Kantian and Utilitarian Ethics on Capital Punishment. Journal of Sustainable Society, 7(1), 5-11.

Ushie, A. I. (2018). The Hermeneutic Narrative of Political Corruption: In and Beyond the Known. International Journal Of Integrative Humanism Vol. 10 No. 2, 39.

Vasser, M. (2017). Grant slaves equality: Re-examining the translation of Colossians 4:1. Tyndale Bulletin, 68(1), 59-71.

Yta, E. M. (2015). The Arts Teacher: Enriching Pedagocy through Arts Based Instruction. A Journal of Theatre \& Media Studies 1 (1), 111-117. 